\title{
Ancient History 1986-1990
}

\author{
Mats Cullhed
}

\begin{abstract}
The author gives an overview of recent Swedish research in ancient history and comments briefly on the future of the subject in Swedish universities.
\end{abstract}

Mats Cullhed, Department of Classical Archaeology and Ancient History, Gustavianum, S-753 lo Uppsala, Sweden.

In the preceding bibliography on this subject, published in 1987, Hugo Montgomery remarked on the limited quantity of writings by Swedish scholars within the field of ancient history. Seven years later the situation is essentially the same. Within the four departments of classical archaeology and ancient history, archaeology draws considerably more attention than Greek or Roman history, and knowledge of Latin and Greek is the exception rather than the rule among students. But, if the study of ancient history does not thrive, it would nevertheless be unfair to describe it as an endangered species, as the following list of books and articles demonstrates.

The study of politics and of political institutions, once the central concern of historical writing, has yielded ground to religious, social and economical history, in Sweden as elsewhere, but there are still several Swedish scholars active within this field of research. E. Wistrand has published studies of two central concepts in Roman politics, auctoritas and felicitas. He shows (E. Wistrand 1986) how the auctoritas of a Roman politician should comprise the willingness to invite, if not necessarily to follow consilium, 'advice'. This attitude could induce cooperation more effectively than the highhanded use of imperium. Wistrand has also traced (E. Wistrand 1987) how felicitas developed from a favour that was granted by the gods and derived from auspicia, to being considered, due to influence from the Hellenistic East during the Late Republic, as a personal quality of a commander. M. Cullhed has proposed an alternative interpretation of the emperor Maxentius' unorthodox princeps title from the first months of his reign (Cullhed 1989). It is suggested that the title was not chosen to appease Galerius, in the hope of being recognized by him as a member of the tetrarchy, but rather to state Maxentius' independence vis-à-vis his father Maximian. B. Thomasson has published his third and concluding volume on Imperial provincial governors (Thomasson 1990).

Within what may broadly be termed "social history" a few works can be mentioned. M. Wistrand writes on the attitudes of Roman authors towards games. In general, the literary sources are critical, but there are differences between the different types of games: while the gladiatorial contests could be appreciated for promoting virtus, the theatre gets a consistently poor rating (M. Wistrand 1990). Ö. Wikander has continued his prosopographical studies of Italic families (Ö. Wikander 1989b, 1990a).

Aspects of the ancient economy have been focused on in several studies. T. Linders has continued her investigations of the significance of Greek temple treasures and inventories. She finds that the treasures should not be seen as financial reserves, but 
as impressive display, designed to demonstrate the piety, wealth and power of the city (Linders 1987). Her studies of Delian inventories have made her conclude that the inventories were not actually consulted as records, but were monuments of actions performed (Linders 1988a, 1988b). She has also proposed an interpretation of kerchnos in inventory lists as designating small pieces of jewellery, decorated with granulation (Linders 1990). The Athenian grain trade has been studied by $\mathrm{H}$. Montgomery, who explains the pre-eminence of metics in this sphere as the result less of Athenian disdain for trade in itself than of the greater competence of the metics in the risky business of long-distance trade (Montgomery 1986b). Ö. Wikander has written on the commercial activities of the Roman aristocracy, admitting that agriculture remained fundamental but claiming that the local production of terracottas pottery, roof-tiles, bricks - on their estates was an important supplementary activity down to the end of the Republic (Ö. Wikander 1987).

Interest in the history of religions has produced several works. L. Portefaix has made use of reception theory in her study (Portefaix 1988) of how New Testament texts were received by the women of Philippi. She describes the city, its pre-Christian cults, the role played by women in these as well as the general conditions of female existence as a background to her analysis. H. Montgomery has devoted several articles to the organization of the Church during the third century A.D., and especially to the significance of the bishop's office in this context (Montgomery 1986a). The behaviour of Saint Cyprian as bishop of Carthage is seen as the attitude of a patronus towards his clients (Montgomery 1988). The ecclesiastical organization is viewed as a good deal more sophisticated and more influenced by the structures of civic life than earlier theories have made out. The scope for acting as a patronus within the structure of the Church may have made membership attractive to wealthy Romans well before the time of Constantine (Montgomery 1990). Finally, B.-M. Näsström has studied aspects of the cult of Attis and Cybele. The rite of castration (Näsström 1989) is interpreted as aiming at a 'liminal' status, above the conditions of mankind, and thus leading to salvation. In her thesis (Näsström 1990) she entered on the subject of the Emperor Julian's interpretation, in neo-Platonic terms, of the cult of Magna Mater.

Ö. Wikander has continued his work in another field, arguing, with Roman watermills as his most important examples, that the traditional view of the backwardness of ancient technology is oversimplified. (Ö. Wikander 1986, 1989a, 1990b). P. Reimers has studied the literary sources for another aspect of ancient technology, city drainage (Reimers 1989).

Roman topography as treated by the literary sources has been at the centre of a number of articles. H. Erkell has written on the Germalus and on the Ara Maxima (Erkell 1987), and $\AA$. Fridh on the Esquiline area (Fridh 1987). Erkell's commentary to the latter article was promptly answered by Fridh (Erkell 1990, Fridh 1990).

A number of other items may be collected at the end of this list. J. Svenbro has collected a number of studies on how the practice of reading aloud gave voice to "speaking" objects in early Greece, in a culture where literacy thus remained "oral" (Svenbro 1988) - a state of affairs that lasted until silent reading started developing during the late fifth century B.C. Svenbro also analyses a Greek fable as an allegory of poetry itself (Svenbro 1990). B. Kurtén Lindberg discusses possible changes in gender patterns in late fifth-century Athens, using Aristophanes as her source (Kurtén-Lindberg 1987). The study of Lycophron's descriptions of sanctuaries in southern Italy in the Alexandra leads I. Edlund (Edlund 1987) to assume a Roman audience of the second 
century B.C. for this work. $\AA$. Fridh rids the name of Caesar from any etymological connection with Caesarian birth (Fridh 1986).

Lastly, the constant flow of popular articles on subjects related to ancient history deserves to be mentioned, though it has been impossible to include them in this bibliography. Most of them can be found in the following magazines: Hellenika and Romhorisont (edited by the friends of the Swedish Institutes in Athens and Rome, respectively), and Medusa, which takes an interest in all aspects of the ancient world.

As to the future of ancient history in Sweden, one need not worry too much about sheer survival. In all likelihood there will always be a small but steady number of graduate students, whose interests will take them into the subject. The problem is rather that of finding ways to attract more students than today. The authors included in this bibliography are members of the departments of classical archaeology and ancient history, but also classical philologists, and scholars from the faculty of theology. In one way this is all for the best: it favours a variety of approaches and perspectives to the study of ancient history. On the other hand, the dispersal of an already restricted number of scholars over different universities and departments has undoubtedly contributed to making this discipline less "visible" than classical archaeology to students. A united effort is needed to show ancient history as an exciting and intellectually rewarding field of study. If that is accomplished, there is a fair chance that future bibliographies on ancient history will need more pages than these.

\section{English revised by Laura Wrang.}

\section{REFERENCES}

Cullhed, M. 1989. Maxentius as princeps. Opuscula Romana 17. 9-19.

Edlund, I. 1987. The sacred geography of southern Italy in Lycophron's Alexandra. Opuscula Romana 16. 43-49.

Erkell, H. 1987. Varroniana III. Studi topografici. Il culto all'Ara maxima. Varro, De lingua latina V 51-54 e VI 54. Opuscula Romana 16. 51-57.

- 1990. From the Esquiliae to the Esquiline. Eranos 88. 125-137.

Fridh, Å. 1986. Myten om kejsarsnittet. In:Vetenskap och omvärdering. Till Curt Weibull på hundraårsdagen 19 augusti 1986. Göteborg. 63-68.

- 1987. Three notes on Roman toponymy and topography. Eranos 85.115-133.

- 1990. Esquiliae, Fagutal and Subura once again. Eranos 88. 139-161.

Kurtén-Lindberg, B. 1987. Women's Lib i Aristophanes Athen? (SIMA pocket-book 53). Göteborg.

Linders, T. 1987. Gods, gifts, society. In: Gifts to the Gods. Proceedings of the Uppsala
Symposium 1985 (Boreas 15). Eds. T. Linders \& G. Nordquist. Uppsala. 115-122.

- 1988a. Continuity in change. The evidence of the temple accounts of Delos. In: Early Greek Cult practice. Proceedings of the Fifth International Symposium at the Swedish Institute at Athens, 26-29 June, 1986 (Acta Ath- $4^{\circ}, 38$ ), ed. by R. Hägg, N. Marinatos \& G. Nordquist. Stockholm. 267-270.

- 1988b. The purpose of inventories: a close reading of the Delian inventories of the Independence. In: Comptes et inventoires dans la cité grecque. Actes du collogue international d'épigraphie tenu à Neuchâtel du 23 au 26 septembre 1986 en l'honneur de Jacques Tréheux (Université de Neuchâtel, Recueil de travaux publ. par la faculté des Lettres, fasc. 40). Rec. et éd. par D. Knoepfler. Neuchâtel \& Genève. 37-47.

- 1990. Kerchnos and kerchnion-not kernos but granulation. OpusculaAtheniensia 17.229-230.

Montgomery, H. 1986a. Konstantin, Cyprianus och makten i kyrkan. Kyrkohistorisk årsskrift 1986. 41-50. 
- 1986b. "Merchants fond of corn": Citizens and foreigners in the Athenian Grain Trade. SymbOsl 56. 43-61.

- 1988. Saint Cyprian's secular heritage. In: Studies in Ancient History and Numismatics presented to Rudi Thomsen. Aarhus. 214-223.

- 1990. Kyrklig autonomi på 200-talet. Patristica Nordica 3 (Religio 32). Lund. 77-99.

Näsström, B.-M. 1989. The Abhorrence of Love. Studies in rituals and mystic aspects in Catullus' poems of Attis (Acta Universitati Upsaliensis, Uppsala Women's Studies, A: Women in Religion 3). Uppsala.

- 1990. Mother of the Gods and Men. Some aspects of the religious thoughts in Emperor Julian's Discourse on the Mother of the Gods (Lund Studies in African and Asian Religions 6). Lund.

Portefaix, L. 1988. Sisters Rejoice. Paul's Letter to the Philippians and Luke-Acts as Received by First-Century Philippian Women (Coniectanea Biblica, New Testament Series 20). Uppsala.

Reimers, P. 1989. "Opus omniu dictu maximum". Literary sources for the knowledge of Roman city drainage. Opuscula Romana 17.137 141.

Svenbro, J. 1988. Phrasikleia. Anthropologie de la lecture en Grèce ancienne (Textes à l'appui). Paris.
- 1990. La cigale et les fourmis. Voix et ècriture dans une allégorie grecque (Lectiones Boëthianae 7). Opuscula Romana 18. 7-21.

Thomasson, B. E. 1990. Laterculi praesidum 3. Göteborg.

Wikander, Ö. 1986. Framsteg eller stagnation? Nyare strömningar i antik teknikhistoria. Polhem 3. 145-164.

- 1987. Senators and equites. II. The aristocracy as agents of production. Opuscula Romana 16. 137-145.

- 1989a. Ausonius' saw-mills - once more. Opuscula Romana 17. 185-190.

- 1989b. Senators and equites. III. The case of the Saufeii. Opuscula Romana 17. 205-212.

- 1990a. Senators and equites. IV. The case of the Egnatii. Opuscula Romana 18. 207-211.

- 1990b. Water-power and technical progress in antiquity. In: Ancient Technology. Finnish Institute at Athens. Symposium held 30.3-4.4 1987. Helsinki. 68-84.

Wistrand, E. 1986. Auctoritas. In: Vetenskap och omvärdering. Till Curt Weibull på hundraårsdagen 19 augusti 1986. Göteborg. 235245.

- 1987. Felicitas imperatoria (Studia graeca et latina Gothoburgensia 48). Göteborg.

Wistrand, M. 1990. Violence and entertainment in Seneca the Younger. Eranos 88. 31-46. 